\title{
KAJIAN SKALA PADA BANGUNAN TRADISIONAL ANGKOLA (Studi Kasus : Museum GKPA, Silangge)
}

\author{
Fernanda Sitanggang ${ }^{(1)}$; Shanty Silitonga, ST.,MT ${ }^{(2)}$, Putri P Napitupulu, ST., MT ${ }^{(3)}$
}

(1) Mahasiswa, prodi arsitektur, fakultas teknik, universitas katolik santo thomas sumatera utara

(2) Staff pengajar, prodi arsitektur, fakultas teknik, universitas katolik santo thomas sumatera utara Email : shanty.silitonga@gmail.com

(3)

Staff pengajar, prodi arsitektur, fakultas teknik, universitas katolik santo thomas sumatera utara

Email: putrin70@gmail.com

\begin{abstract}
This research raises the scale study of traditional angkola buildings with a case study of the GKPA Museum, Silangge. This building consists of the elements making up the space, both indoor and outdoor. The building blocks in the building include: the head of the building (ni orbo horns, closed capillaries, dadap na tolu, and lisplank), the building body (doors, windows, vents, and poles), and the legs of the building (foundations, columns, and stairs). While the building elements outside the building include: buildings with supporting functions (Debora orphanage and Debora orphanage study room), Debora orphanage field, and some vegetation around the Angkola Museum. The scale that will be examined in this study is the human scale (human as a benchmark) of the elements forming the outer space of traditional Angkola buildings. The scale study will be carried out by analyzing the human scale of the building with a predetermined observation point. This study was classified in research that uses descriptive methods with qualitative analysis. Data analysis with descriptive analysis techniques that use benchmarks. Evaluation research that aims to assess the extent to which the variables studied are in accordance with predetermined benchmarks. The benefit of this research is finding a scale study found in Angkola's traditional building, whether the building is classified as good with the scale of the outer space that exists in the elements of the building's outer space.
\end{abstract}

\section{Keywords : Scale, Traditional Building}

\section{Abstrak}

Penelitian ini mengangkat kajian skala pada bangunan tradisional angkola dengan studi kasus Museum GKPA, Silangge. Bangunan ini terdiri dari elemen-elemen penyusun ruangnya, baik itu ruang dalam maupun ruang luar. Elemen-elemen penyusun ruang dalam bangunan tersebut meliputi : kepala bangunan (tanduk ni orbo, tutup ni ari, dalihan na tolu, dan lisplank), badan bangunan (pintu, jendela, ventilasi, dan tiang), dan kaki bangunan (pondasi, kolom, dan tangga). Sedangkan elemen-elemen penyusun ruang luar bangunan tersebut meliputi : bangunan dengan fungsi pendukung (panti asuhan Debora dan ruang belajar panti asuhan Debora), lapangan panti asuhan Debora, dan beberapa vegetasi yang ada disekitar Museum Angkola. Skala yang akan diteliti pada penelitian ini yaitu skala manusia (manusia sebagai titik tolak ukur) terhadap elemen-elemen pembentuk ruang luar bangunan tradisional Angkola. Kajian skala yang akan dilakukan dengan menganalisa skala manusia terhadap bangunan dengan titik pengamatan yang sudah ditentukan. Penelitian ini digolongkan dalam penelitian yang menggunakan metode deskriptif dengan analisis kualitatif. Analisis data dengan teknik analisis deskriptif yang menggunakan tolak ukur. Penelitian evaluasi yang bertujuan untuk menilai sejauh mana variable yang diteliti telah sesuai dengan tolok ukur yang sudah ditentukan. Manfaat penelitian ini yaitu menemukan kajian skala yang terdapat pada bangunan tradisional Angkola, apakah bangunan tersebut tergolong baik dengan skala ruang luar yang ada pada elemen-elemen ruang luar bangunan tersebut.

Kata Kunci: Skala, bangunan tradisional 


\section{Pendahuluan}

Skala dalam Arsitektur menunjukkan perbandingan antara elemen bangunan atau ruang dengan suatu elemen tertentu yang ukurannya sesuai dengan manusia. Skala dalam arsitektur adalah suatu kemampuan manusia secara kualitas untuk membandingkan bangunan atau ruang. Pada ruang-ruang yang masih terjangkau oleh manusia skala ini dapat langsung dikaitkan dengan ukuran manusia. Pada ruang yang melebihi jangkauan manusia penentuan skala harus didasarkan pada pengamatan visual dengan membandingkannya dengan ketinggian manusia sebagai tolak ukurnya (Ezpada, 2014).

Proporsi berkaitan dengan keberadaan hubungan tertentu antara ukuran bagian terkecil dengan ukuran keselurahan. Proporsi merupakan hasil perhitungan bersifat rasional dan terjadi bila dua buah perbandingan adalah sama. Proporsi merupakan hubungan antar bagian dari suatu desain atau hubungan antara bagian dengan keseluruhan. Oleh karena itu suatu perbandingan akan merupakan dasar dari setiap sistem proporsi yaitu suatu nilai yang memiliki harga tetap, dapat digunakan sebagai pembanding yang lain. Bahwa, suatu proporsi yang baik terletak pada hubungan antara bagian-bagian suatu bangunan atau antara bagian bangunan dengan bangunan secara keseluruhan (Prinsip Perancangan, 2014).

Bangunan tradisional Angkola tersusun atas beberapa elemen - elemen penyusun ruang yang merupakan komponen-komponen yang melekat dan menjadi satu dengan ruang dan berfungsi membatasi ruangan tersebut sekaligus menandakan batas masuk/keluar ruangan tersebut. Elemen penyusun ruang tersebut meliputi : kepala bangunan (tanduk ni orbo, tutup ni ari, dalihan na tolu, dan lisplank), badan bangunan (pintu, jendela, ventilasi, dan tiang), dan kaki bangunan (pondasi, kolom, dan tangga).

Pengamatan penelitian ini difokuskan pada sebuah bangunan tradisional Angkola di Desa Silangge, dengan tujuan melakukan kajian terhadap skala dan proporsi pada elemen-elemen bangunan. Analisis dilakukan dengan cara mendeskripsikan elemen per elemen berdasarkan bagian - bagian yang ditemukan pada obyek penelitian.

\section{Landasan Teori}

\subsubsection{Pengertian Skala}

Skala adalah ukuran (besar/kecil) yang terlihat jelas dan memiliki tujuan tertentu. Skala sebuah bangunan ialah kesan yang ditimbulkan bangunan itu mengenai ukuran besarnya. Skala biasanya diperoleh dengan besarnya bangunan dibandingkan dengan unsur-unsur berukuran manusiawi yang ada di sekitarnya. (Munir, 2016)

Skala bertitik tolak pada cara pandang atau penilaian besarnya sesuatu dalam hubungannya dengan sesuatu yang lain. Dalam permasalahan skala, biasanya selalu membandingkan sesuatu hal dengan hal lainnya. Skala dalam Arsitektur adalah suatu kemampuan manusia secara kualitas untuk membandingkan bangunan atau ruang. Pada ruang - ruang yang masih terjangkau oleh manusia skala ini dapat langsung dikaitkan dengan ukuran manusia. Pada ruang yang melebihi jangkauan manusia penentuan skala harus didasarkan pada pengamatan visual dengan membandingkannya dengan ketinggian manusia sebagai tolak ukurnya. Dalam arsitektur yang dimaksud dengan skala adalah hubungan yang harmonis antara bangunan beserta komponennya, seperti perabot, manusia maupun pepohonan (D.K Ching, 1996). 


\subsubsection{Jenis - jenis Skala}

a. Skala Manusia (Ashihara, 1970)

Skala manusia didasarkan pada jarak dan ketinggian bangunan atau lingkup area yang ada dari sudut pandangan manusia yang antara sudut $30^{\circ}-65^{\circ}$. Sudut pandang yang normal manusia adalah 27 derajat, jadi untuk perbandingan $\mathrm{D} / \mathrm{H}=27$ derajat. Pada dasarnya sudut pandangan mata manusia secara normal pada bidang vertical adalah 60 derajat, tetapi bila melihat secara intensif maka sudut pandangan mata berkurang 1 derajat.

Bila orang melihat lurus ke depan, maka bidang pandangnya vertical di atas bidang pandangan horizontal mempunyai sudut 40 derajat atau 2/3 seluruh sudut pandangan mata. Dan orang dapat melihat keseluruhan pandangan bila sudut pandangnya 27 derajat atau bila $\mathrm{D} / \mathrm{H}=2$ ( jarak dibagi dengan tinggi = 2). Orang akan merasa terpisah dari bangunan bila melihat dari jarak sejauh 2 x tinggi bangunannya, ini berarti sudut pandangannya 27 derajat. Bila orang ingin melihat sekelompok bangunan sekaligus maka diperlukan sudut 18 derajat, ini berarti dia harus melihat dari jarak sejauh pandangan $3 \times$ tinggi bangunan.

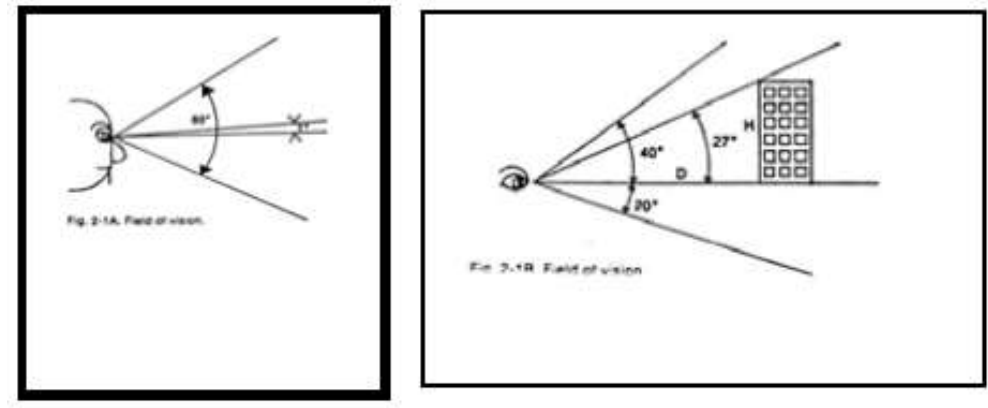

Gambar.2.1 Field Of Vision

(Sumber : Ashihara, 1970)

Dinding setinggi $30 \mathrm{~cm}$ dan $60 \mathrm{~cm}$ secara visual hampir tidak mempunyai daya mengruang dan tidak menimbulkan kesan yang formal sedangkan tinggi $90 \mathrm{~cm}$ tidak merubah keaadaan secara radikal. Bila tinggi dinding menjadi $120 \mathrm{~cm}$ dinding tersebut dapat menutupi sebagian besar badan orang dan menimbulkan kesan/suasana aman meskipun dapat berfungsi pemisah ruang tetapi secara visual masih mempunyai efek ruang yang kontiniu.

Bila dinding tingginya menjadi $150 \mathrm{~cm}$, dinding sudah mempunyai daya mengruang dan bila tinggi dinding lebih dari $180 \mathrm{~cm}$, dinding dapat menutupi seluruh tubuh manusia dan hampir dalam semua hal dapat memberi daya mengruang yang kuat. Jadi kesan mengruang dapat dicapai bila tinggi dinding melebihi tinggi manusia dan memutuskan pandangan yang menerus dari lantai. Selain itu menimbulkan kesan enclosure yang kuat. 


\section{Teori Enclosure (Ashihara, 1970) :}

Kualitas pembatas ruang luar, ditentukan oleh tinggi pembatas serta macam material yang digunakan, baik soft ataupun hard material. Tinggi suatu pembatas, sangat erat hubungannya dengan tinggi mata orang. Misalnya dinding pembatas setinggi $63 \mathrm{~cm}$, kualitasnya hampir tidak mempunyai daya mengruang, meskipun dapat berfungsi sebagai pembatas.

Apabila dinding setinggi $60 \mathrm{~cm}$, atau $90 \mathrm{~cm}$ atau bahkan $120 \mathrm{~cm}$, dinding tersebut dapat menutupi sebagian besar badan orang, dan menimbulkan kesan aman, meskipun dapat berfungsi sebagai pemisah ruang, akan tetapi secara visual masih mempunyai efek ruang yang kontinu. Untuk tinggi lebih dari $180 \mathrm{~cm}$ yang menutup seluruh bagian tubuh manusia, maka hal ini dapat memberi "daya meruang" yang sangat kuat. Jadi kesan meruang dapat dicapai bila, tinggi dinding melebihi tinggi manusia dan memutuskan pandangan yang menerus dari lantai.

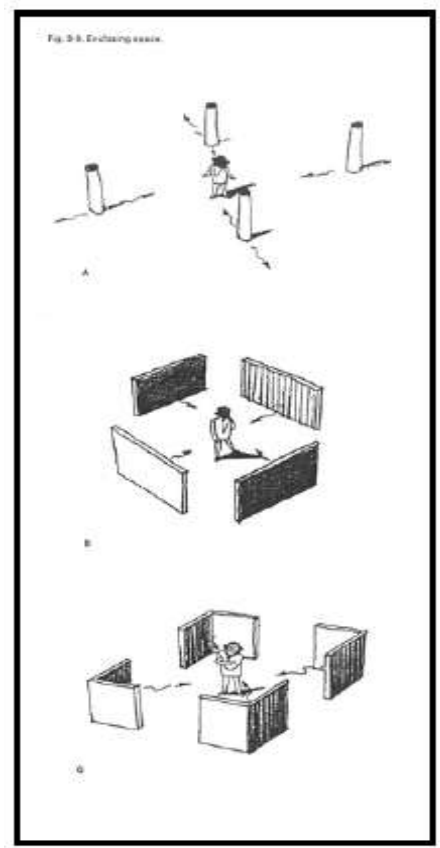

Gambar 2.2 Enclosure

(Sumber : Ashihara, 1970)

Rumus tentang perbandingan antara tinggi dan jarak $\mathrm{D} / \mathrm{H}>1$ dapat digunakan untuk merancang kualitas ruang luar yang diinginkan. Bila $\mathrm{D} / \mathrm{H}<1$, maka pembukaan ruang yang terjadi mempunyai nilai sebagai pintu masuk/keluar yang merangsang orang untuk melaluinya $(\mathrm{H}=$ tinggi dinding, $\mathrm{D}=$ lebar bukaan). Bila $D / H=1$, maka yang terjadi adalah keseimbangan. Dan bila $D / H>1$, maka pembukaan vertical akan lebih luas, sehingga kualitas dari pembukaan menyebabkan "daya meruang" dinding yang meliputi ruang luar tersebut menjadi berkurang. 

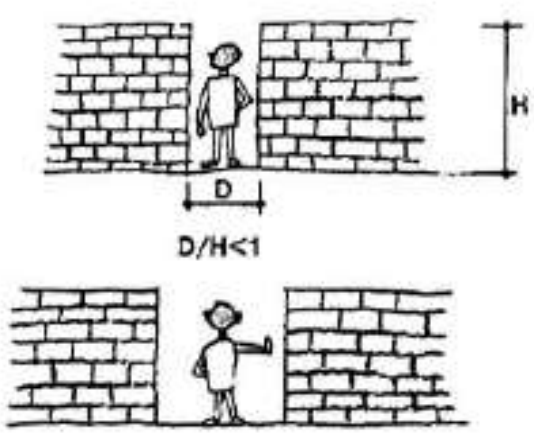

$\mathrm{D} / \mathrm{H}-1$

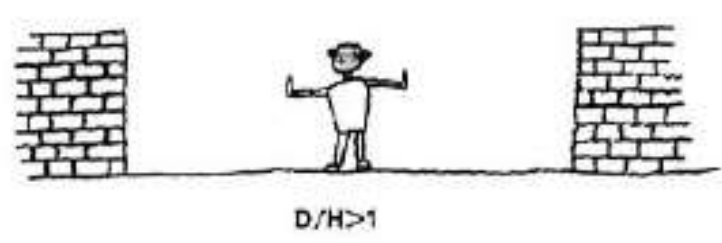

\section{Gambar 2.3 Ilustrasi Perbandingan D/H}

(Sumber : Ashihara, 1970)

Perbandingan antara jarak antar bangunan (D) dan tinggi bangunan (H) sebagai berikut, (Ashihara, 1970) :

- $\mathrm{D} / \mathrm{H}=1 \quad$ : ruang terasa seimbang dalam perbandingan jarak dan tinggi bangunannya.

- $\mathrm{D} / \mathrm{H}<1 \quad$ : ruang yang terbentuk akan terlalu sempit dan memberikan rasa tertekan.

- $\mathrm{D} / \mathrm{H}>1 \quad$ : ruang terasa agak besar.

- $\mathrm{D} / \mathrm{H}>/ 2$ : pengaruh ruang tidak akan terasa.

Menurut Spriegen, perbandingan antara tempat seseorang berdiri (D) dengan objek tinggi bangunannya (H) bila, (Ashihara, 1970) :

- $\mathrm{D} / \mathrm{H}=1 \quad$ : cenderung memperhatikan detail daripada keseluruhan bangunan.

- $\mathrm{D} / \mathrm{H}=2 \quad$ : cenderung untuk melihat bangunan sebagai sebuah komponen keseluruhan bersama dengan detailnya.

- $\mathrm{D} / \mathrm{H}=3 \quad$ : bangunan terlihat dalam hubungan dengan lingkungannya.

- $\mathrm{D} / \mathrm{H}=2 \quad$ : bangunan dilihat sebagai pembatas ke depan saja.

\section{b. Skala Ruang Intim.}

Merupakan skala ruang yang kecil sehingga memberikan rasa perlindungan bagi manusia yang berada di dalamnya. Pengertian kecil bukan berarti dikecilkan hingga menjadi kerdil. Sebagai contoh, sebuah taman pada bangunan rumah tinggal cenderung untuk membentuk ruang intim. Pada ruang intim ini hampir seluruh detail elemen perkerasan atau tanaman akan terlihat jelas. Bentuk, tekstur, warna, dan aroma perlu menjadi pertimbangan perancangan dalam menerapkan skala ruang kecil. Biasanya untuk skala ruang kecil keintiman akan timbul karena gerak manusia sangat terbatas (Rahmana, 2011) 


\section{c. Skala Ruang Monumental.}

Merupakan skala ruang yang besar dengan suatu objek yang mempunyai nilai tertentu sehingga manusia akan merasakan keagungan dari ruang tersebut. Manusia akan terangkat perasaan spiritualnya dan terkesan pada keagungan yang dirasakannya. Tugu Monumen Nasional merupakan suatu contoh yang jelas pada penggunaan skala monumental (Rahmana, 2011).

\section{d. Skala Ruang Kota.}

Merupakan skala ruang yang dikaitkan dengan kota serta lingkungan manusianya, sehingga manusia merasa memiliki atau kerasan pada lingkungan tersebut. Plasa kota merupakan suatu contoh yang jelas. Ukuran lugs plasa sebaiknya minimum sama dengan bangunan utama dari plasa tersebut, sedangkan maksimum sebaiknya dua kali bangunan utama. Plasa yang besar dan dikelilingi oleh bangunan kecil menjadi tidak sesuai skalanya, demikian pula halnya bila sebuah objek menara tinggi di antara rumahrumah kecil (Rahmana, 2011).

\section{e. Skala Ruang Menakutkan.}

Pada skala ini objek bangunan mempunyai ketinggian yang berada jauh di atas skala ukuran manusia. Hal ini akan terasa bila kita berjalan di antara bangunan tinggi dengan jarak antarbangunan yang berdekatan (Rahmana, 2011).

\section{Metode Penelitian}

Metode penelitian yang digunakan dalam penelitian ini adalah secara deskriptif dengan analisis kualitatif. Analisis data dengan teknik analisis deskriptif kualitatif adalah analisis yang menggunakan tolak ukur. Penelitian evaluasi yang bertujuan untuk menilai sejauh mana variable yang diteliti telah sesuai dengan tolok ukur yang sudah ditentukan.

Menganalisis dengan deksriptif kualitatif adalah memberikan predikat kepada variable yang diteliti sesuai dengan kondisi yang sebenarnya. Predikat yang diberikan tersebut dalam bentuk peringkat yang sebanding dengan atau atas dasar kondisi yang diinginkan. Analisis kualitatif dinyatakan dalam sebuah predikat yang menunjuk pada pernyataan keadaan, ukuran kualitas.

Objek pada penelitian ini terdapat di Desa Silangge, Tapanuli Selatan. Penelitian ini berfokus pada kajian skala dan proporsi pada elemen - elemen yang terdapat pada bangunan tradisional Angkola yang terdapat di Desa Silangge, baik pada bagian eksterior bangunan, maupun pada ruang luar sekitar bangunan. 


\section{Analisa}

a. Ditinjau dari Gerbang Utama Museum GKPA Silangge
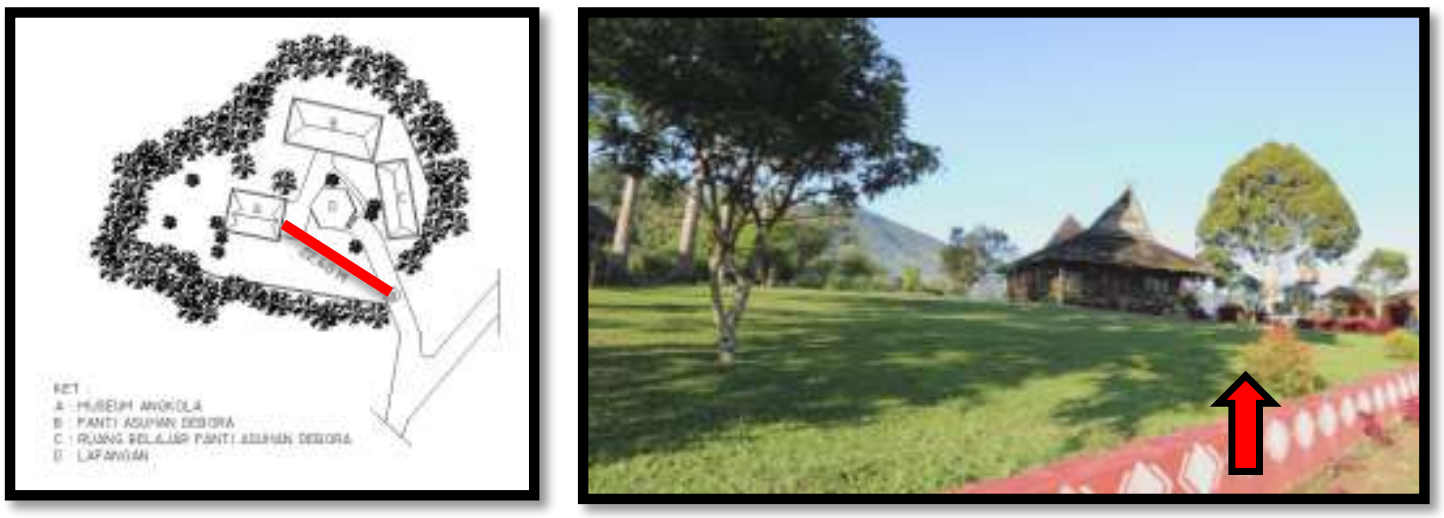

Gambar. 5.8 Ruang Luar Museum GKPA Silangge ditinjau dari Gerbang Utama

(Sumber : Dokumen Pribadi)

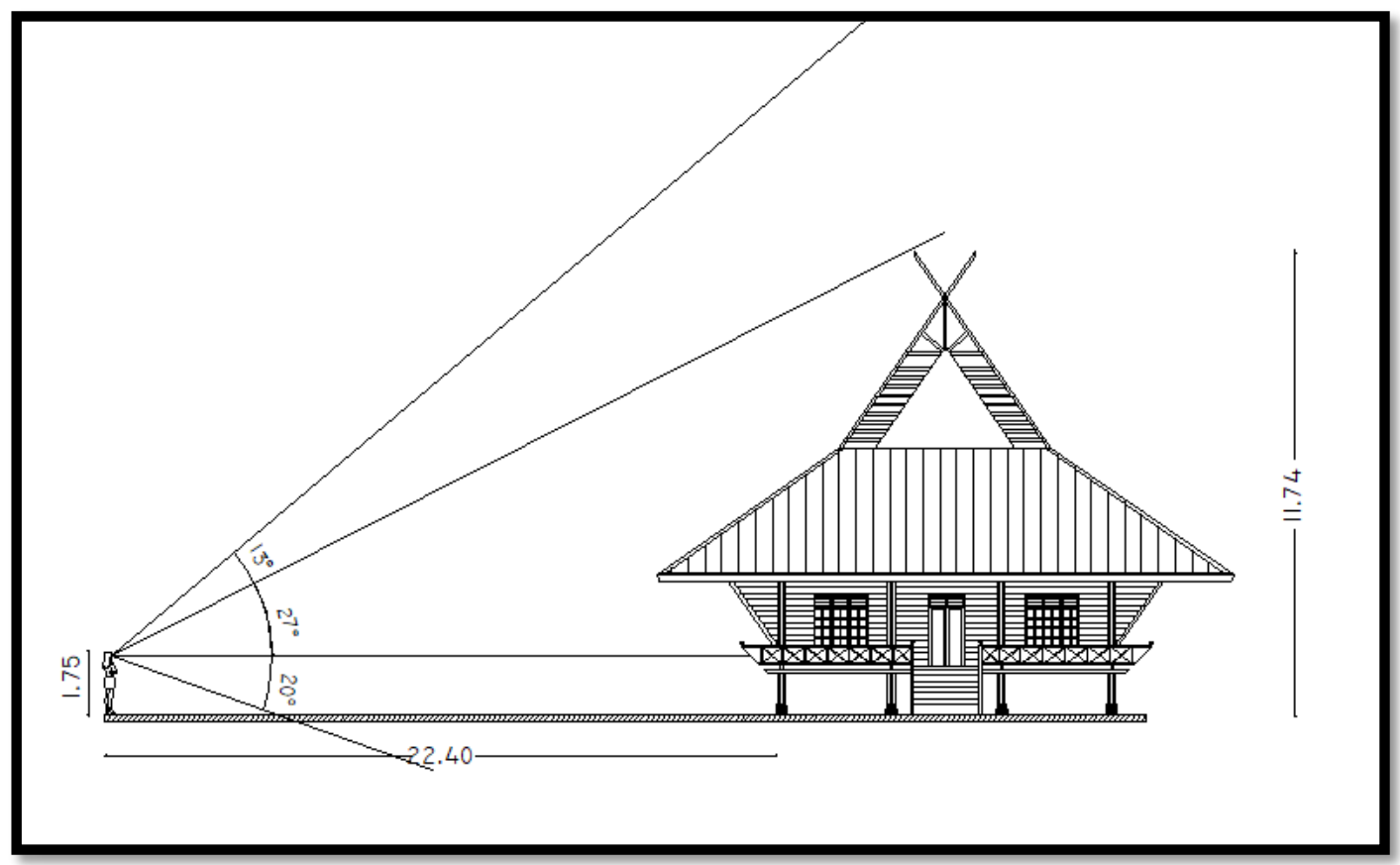

Gambar. 5.10 Pengamat mengamati dari Gerbang Utama

(Sumber : Dokumen Pribadi)

Manusia yang mengamati dari jarak 22.40 M masih dapat menjangkau seluruh bagian bangunan. Diperoleh perbandingan $\mathrm{D} / \mathrm{H}=22.40 / 11.74=1,9$. Diketahui jika $\mathrm{D} / \mathrm{H}>1$, maka bangunan akan membentuk ruang yang terasa agak besar sehingga memberikan kesan yang aman (tidak menakutkan) terhadap si pengamat. 
b. Ditinjau dari Lapangan Museum GKPA Silangge
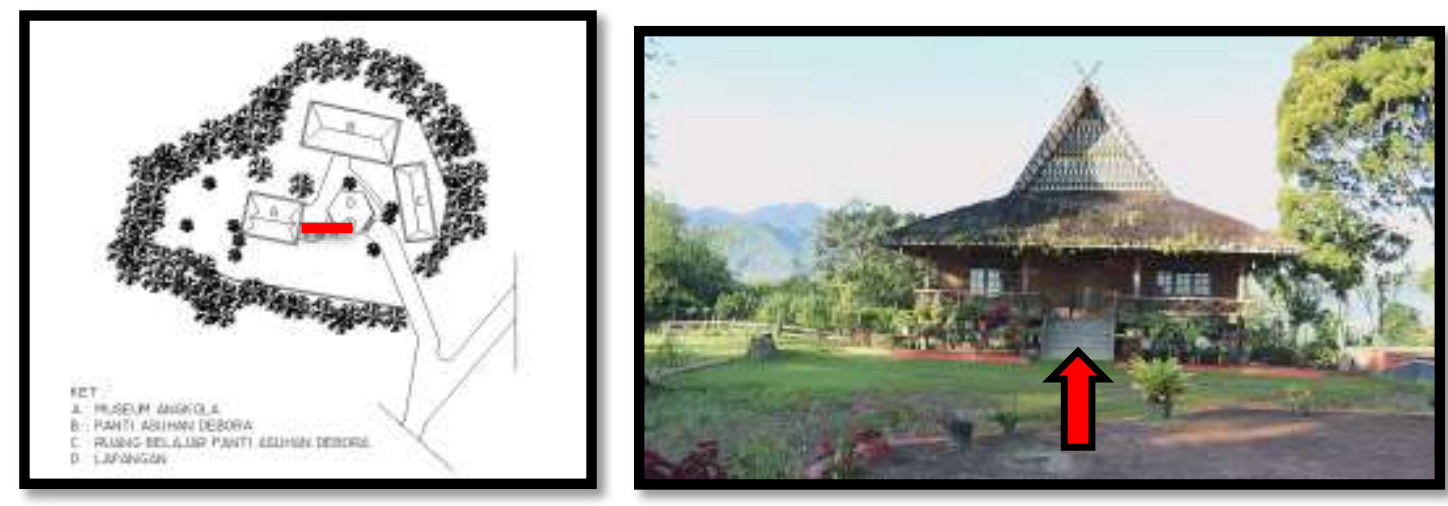

Gambar. 5.11 Ruang Luar Museum GKPA Silangge ditinjau dari Lapangan

(Sumber : Dokumen Pribadi)

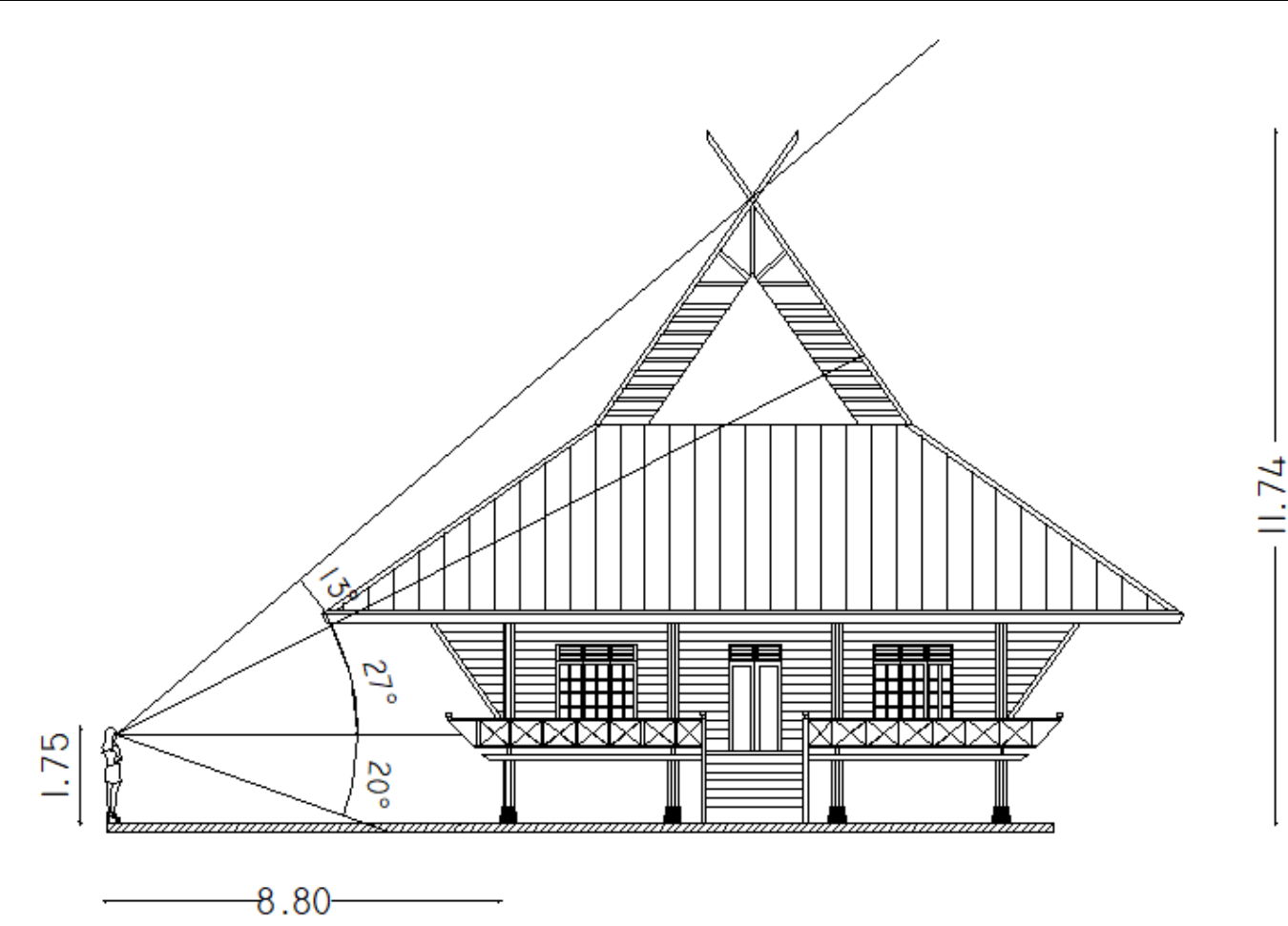

Gambar. 5.13 Pengamat mengamati dari Lapangan

(Sumber : Dokumen Pribadi)

Manusia yang mengamati dari jarak 8.80 M masih dapat menjangkau seluruh bagian bangunan beserta detailnya. Diperoleh perbandingan $\mathrm{D} / \mathrm{H}=8.80 / 11.74=0,74$. Diketahui jika $\mathrm{D} / \mathrm{H}<1$, maka ruang yang terbentuk akan terlalu sempit dan memberikan rasa tertekan, sehingga memberikan kesan yang menakutkan terhadap si pengamat. 
c. Ditinjau dari Panti Asuhan Debora
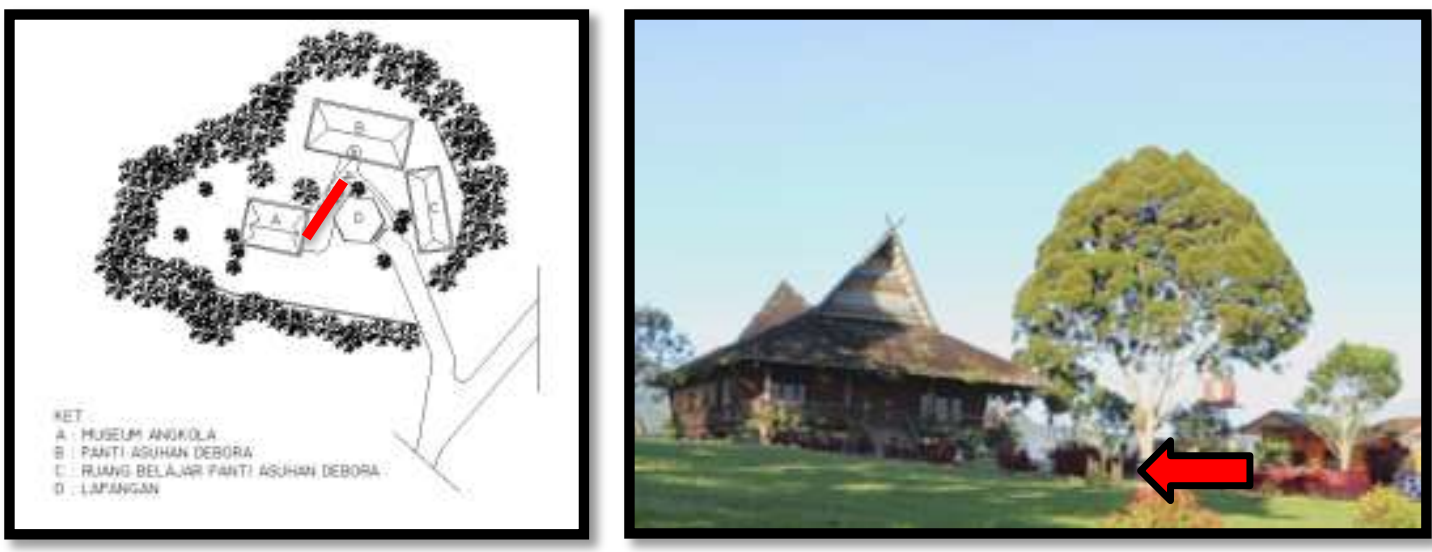

Gambar. 5.15 Ruang Luar Museum GKPA Silangge ditinjau dari Panti Asuhan Debora

(Sumber : Dokumen Pribadi)

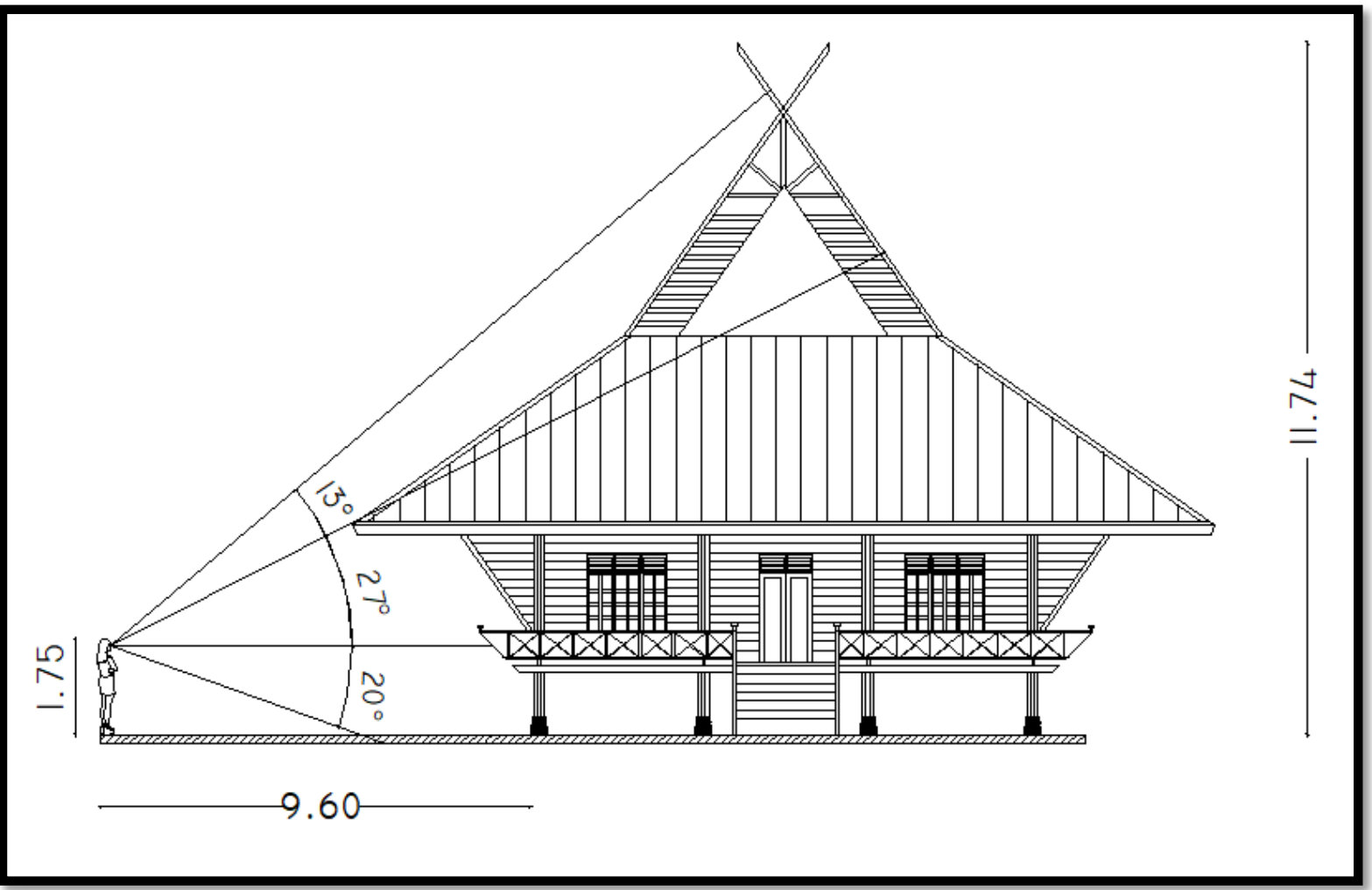

Gambar. 5.16 Pengamat mengamati dari Panti Asuhan

(Sumber : Dokumen Pribadi)

Manusia yang mengamati dari jarak 9.60 M masih dapat menjangkau bagian bangunan tetapi tidak dengan keseluruhan. Diperoleh perbandingan $\mathrm{D} / \mathrm{H}=9.60 / 11.74=0.81$. Diketahui jika $\mathrm{D} / \mathrm{H}<1$, maka ruang yang terbentuk akan terlalu sempit dan memberikan rasa tertekan, sehingga memberikan kesan yang menakutkan terhadap si pengamat. 
d. Ditinjau dari Ruang Belajar Panti Asuhan Debora.
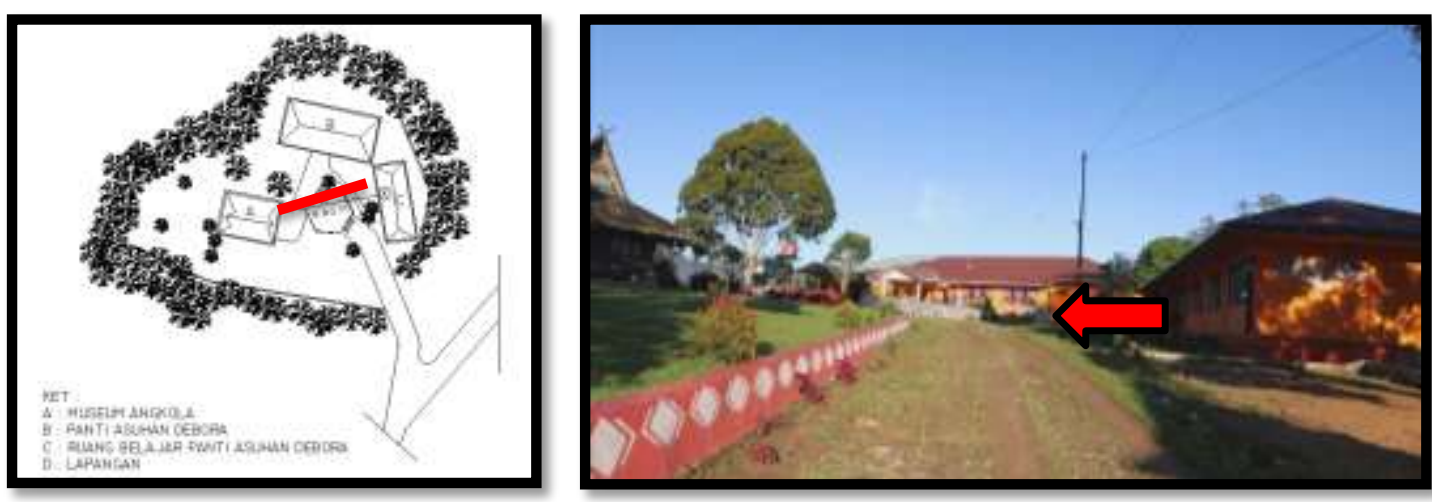

Gambar. 5.18 Ruang Luar Museum GKPA Silangge ditinjau dari Ruang Belajar

(Sumber : Dokumen Pribadi)

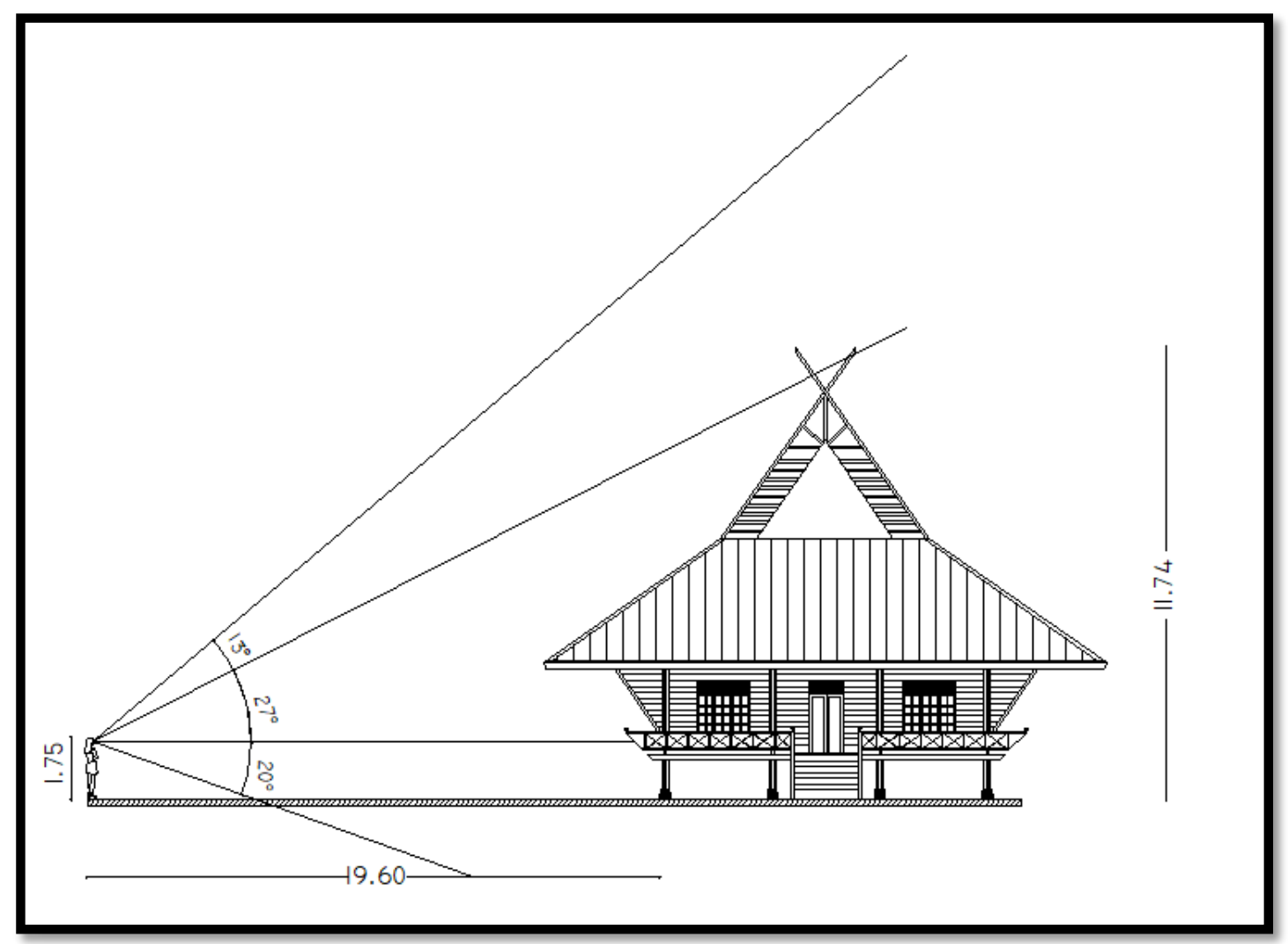

Gambar. 5.19 Pengamat mengamati dari Ruang Belajar

(Sumber : Dokumen Pribadi)

Manusia yang mengamati dari jarak 19.60 M masih dapat menjangkau seluruh bagian bangunan beserta detailnya. Diperoleh perbandingan $\mathrm{D} / \mathrm{H}=19.60 / 11.74=1,6$. Diketahui jika $\mathrm{D} / \mathrm{H}>1$, maka bangunan akan membentuk ruang yang terasa agak besar sehingga memberikan kesan yang aman (tidak menakutkan) terhadap si pengamat. 
e. Ditinjau diantara dua bangunan (Museum Angkola - Ruang belajar panti Asuhan Debora).
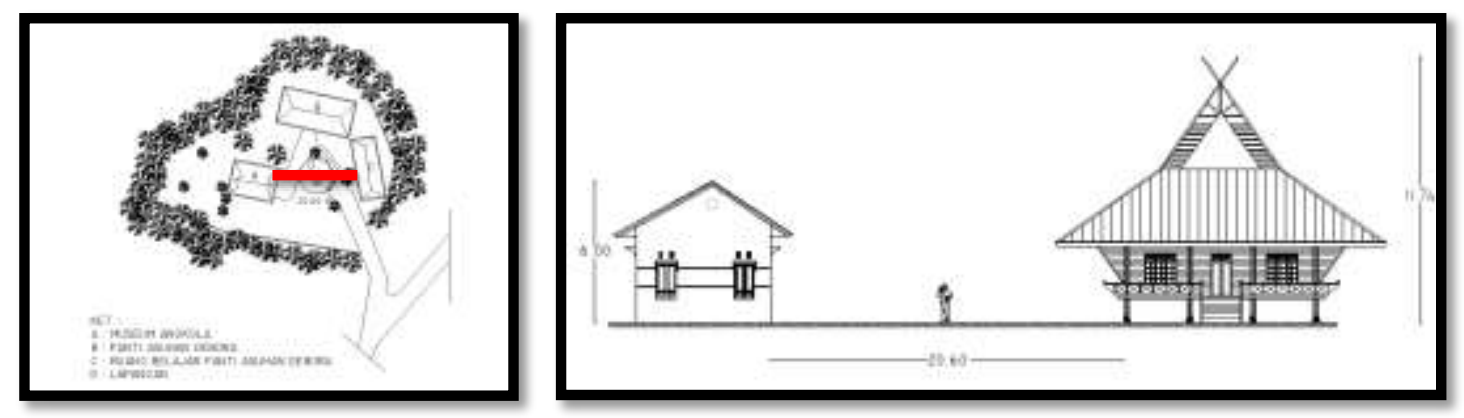

Gambar. 5.21 Manusia mengamati diantara Museum dengan Ruang Belajar

(Sumber : Dokumen Pribadi)

Manusia mengamati di antara Museum Angkola dengan Ruang belajar panti Asuhan Debora. D $=20.60 \mathrm{~m}$ dan $\mathrm{H}=11.74 \mathrm{~m}$. $\mathrm{D} / \mathrm{H}=20.60 / 11.74=1,75$. Diketahui jika $\mathrm{D} / \mathrm{H}>1$, maka pembukaan vertical akan lebih luas, sehingga kualitas dari pembukaan membentuk ruang yang memberikan kesan aman (tidak menakutkan) terhadap si pengamat.

f. Ditinjau diantara dua bangunan (Museum Angkola - Panti Asuhan Debora)
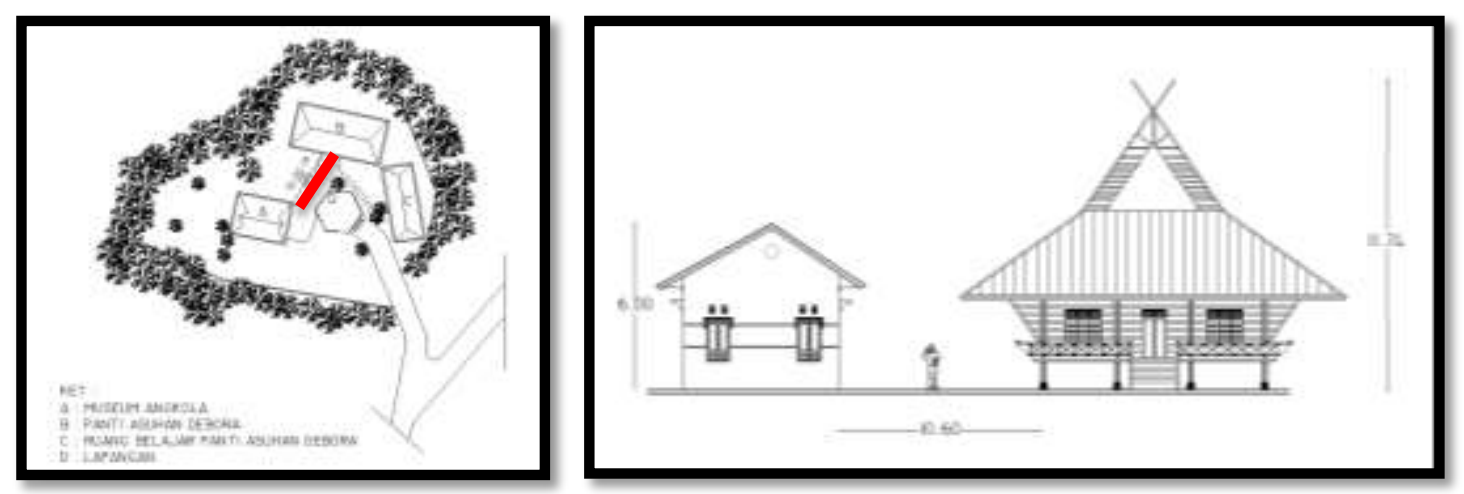

Gambar. 5.23 Manusia mengamati diantara Museum dengan Panti Asuhan

(Sumber : Dokumen Pribadi)

Manusia mengamati diantara bangunan Museum Angkola dengan Panti Asuhan Debora. $\mathrm{D}=$ $10.60 \mathrm{~m}$ dan $\mathrm{H}=11.74 \mathrm{~m} . \mathrm{D} / \mathrm{H}=10.6 / 11.74=0,9$. Diketahui jika $\mathrm{D} / \mathrm{H}<1$, maka ruang yang terbentuk akan terlalu sempit dan memberikan rasa tertekan terhadap si pengamat.

\section{Kesimpulan}

Berdasarkan hasil analisa kajian skala dan proporsi pada bangunan tradisional Angkola yang terdapat di Desa Silangge, Tapanuli Selatan, dapat disimpulkan bahwa, kajian Skala pada Museum Angkola dianalisis dengan menggunakan skala manusia (manusia sebagai tolak titik ukur) dengan beberapa titik pengamatan yang sering digunakan oleh manusia yang berada pada lingkungan tersebut diperoleh kesimpulan bahwa skala manusia pada bangunan tersebut tergolong baik dikarenakan bangunan tersebut membentuk ruang yang memberikan kesan aman terhadap si pengamat. 


\section{Saran}

Untuk ruang luar, sebaiknya diberikan vegetasi di sekitar bangunan agar dapat membentuk ruang yang melingkupi Museum Angkola beserta bangunan lainnya yang berfungsi sebagai pembatas antara Museum Angkola dengan bangunan lain yang berada diluar kawasan Museum tersebut. Untuk bagian pintu masuk/gerbang utama Museum sebaiknya diberikan jarak yang tidak terlalu jauh dari bangunan tersebut, agar manusia yang mengamati dari pintu masuk/gerbang utama dapat melihat/mengamati bangunan tersebut.

\section{Daftar Pustaka}

D.K.Ching, Frank 1996, Arsitektur : Bentuk, Ruang dan Tatanan, Erlangga.

Gunadi, S. 1974. "Perancangan Eksterior dalam Arsitektur" (terjemahan), Fakultas Teknik Arsitektur ITS. Espada, Riez 2014, Skala dalam Arsitektur, no. 5

Munir, Rajil 2016,' Estetika dalam Arsitektur; Pengertian Proporsi, Irama, Skala, Urutan/Sequence, Faktor serta Macam-Macam Skala dan Irama', no. 6. 